Magdalena Toboła-Feliks

ORCID: https://orcid.org/0000-0002-5421-9484

Szkoła Doktorska - Uniwersytet Śląski

\title{
Dąbrówka Wielka - wieś w mieście. Animacja zaangażowana w zachowaniu miejscowego stroju ludowego (mediacja na styku etnologii i performatyki)
}

\author{
Dabrówka Wielka - a village in the city. \\ Animation involved in the preservation of local folk costume \\ (mediation at the borderline between ethnology and \\ performance)
}

\begin{abstract}
In the article I introduce actions concerning the broadly understood revitalization (revival, restoration) of folk costume, undertaken in the village of Dąbrówka Wielka in Piekary Śląskie district. I examine grassroots initiatives aimed at preserving the custom of wearing local folk costumes and at demonstrating local identity and attachment to tradition. These projects can be classified as a magnum opus of the so-called engaged animation, turning modern folk costume wearers into protagonists of pageants that form a specific type of historical reenactment.
\end{abstract}

Keywords: science about culture and religion, folk costume, Rozbark costume, engaged animation, local community, Dąbrówka Wielka

W artykule przybliżam działania dotyczące szeroko rozumianej rewitalizacji (ożywienia, przywrócenia) stroju ludowego podejmowane w miejscowości Dąbrówka Wielka, dzielnicy Piekar Śląskich. Analizuję inicjatywy oddolne zmierzające do zachowania zwyczaju noszenia miejscowego stroju ludowego oraz manifestujące lokalną tożsamość i przywiązanie do tradycji. Przedsięwzięcia te można zakwalifikować jako 
magnum opus tzw. animacji zaangażowanej, czyniącej współczesnych nosicieli stroju bohaterami widowisk wpisujących się w specyficzny rodzaj odtwórstwa historycznego.

Słowa kluczowe: nauki o kulturze i religii, strój ludowy, strój rozbarski, animacja zaangażowana, społeczność lokalna, Dąbrówka Wielka

Odebrano / Received: 19.01.2021

Zaakceptowano / Accepted: 05.10.2021

\section{Wprowadzenie}

Fascynacja strojem ludowym widoczna jest na wielu płaszczyznach. Historia zainteresowania strojem chłopskim wiąże się jednak głównie $\mathrm{z}$ historią etnografii. Szczególny typ kompetencji tej dziedziny nauki sprawił, że jej reprezentanci bardzo szybko odczuli potrzebę zdynamizowania działań na rzecz ocalenia dawnych wartości - treści usankcjonowanych tradycją, artefaktów materialnych oraz określonych typów postępowania i rozumienia świata, czyli tzw. ukrytego wymiaru kultury (Bazielich 1977: 3-4). Strój ludowy będący jednocześnie narzędziem konstruowania kultury, elementem namacalnie manifestującym dziedzictwo kulturowe oraz emanacją indywidualnej świadomości mieszkańców dawnej (historycznie rozumianej) wsi już we wczesnej fazie działań ludoznawców i etnografów zajął w ich badaniach istotne miejsce. Dawniej stanowił on przekaz ściśle skodyfikowany z przestrzenią, w której funkcjonował. Określenie stroju mianem ludowego nierozerwalnie wiązało go zatem $\mathrm{z}$ chłopską warstwą społeczeństwa, wskazując nie tylko na pochodzenie użytkowników stroju, ale również charakteryzując jego wytwórców (Brzezińska 2013: 15-16). Mieszkańcy wsi zwracali uwagę na najdrobniejsze szczegóły regionalnego ubioru paradnego, który pełen był symbolicznych odniesień. Tak jak i dziś - był również łącznikiem z tradycją przodków. Odzwierciedlał on też w różnym stopniu indywidualne historie, nie zawsze w porę zarejestrowane. Stąd współczesne opowieści o strojach ludowych bywają zwykle narracją stworzoną na bazie obiektów tożsamych dla określonej grupy społecznej, nie zaś indywidualnego nosiciela stroju. Tym samym biografia przedmiotu cały czas zostaje $\mathrm{w}$ cieniu, nie ujawniając się. Przypadek Dąbrówki Wielkiej jest zatem o tyle niezwykły, że mamy tu do czynienia z wciąż „żywą tradycją" noszenia miejscowego stroju ludowego. Nie jest to zainteresowanie wtórne, dlatego w wielu przypadkach jesteśmy w stanie orientacyjnie ustalić personalia pierwotnego właściciela danego stroju (należy on z reguły do przodków obecnych posiadaczy konkretnych kompletów odzieży paradnej). Pomimo że z ogromnej puli oryginalnych elementów strojów ludowych obecnych w przeszłości zostało ich w tej dawnej wsi współcześnie niewiele ${ }^{1}$, wciąż jest to znaczący zbiór kolekcji prywatnych - w porównaniu $\mathrm{z}$ ościennymi miejscowościami.

\footnotetext{
1 Sporo miejscowych strojów ludowych przekazano (za pośrednictwem darowizn lub w drodze zakupu) do
} różnych placówek muzealnych, np. Muzeum Śląskiego w Katowicach, Muzeum Górnośląskiego 
Głównym celem mojego artykułu stanie się próba ukazania osobistych predylekcji osób zaangażowanych w eksploatacje dziedzictwa kulturowego wyrażanego za pomocą stroju rozbarskiego ${ }^{2}$ (adekwatnego dla obszaru Dąbrówki Wielkiej), traktowanego nie tylko jako ubiór zakładany na szczególne okazje, ale przede wszystkim element istotny w strategii budowania tożsamości regionalnej. Działania zmierzające w kierunku świadomego powrotu do uświęconej tradycją formy stroju ludowego postrzegam w kategorii swoistej nadbudowy wobec tożsamości lokalnej. Znacząca jest również promocja owego stroju wychodząca poza obręb grupy mieszkańców Dąbrówki Wielkiej. Opiera się ona na świadomym kreowaniu wizji istnienia tu pewnej „enklawy stroju ludowego” (reprezentującego wspomniany typ rozbarski). W świadomości społecznej mieszkańców miast górnośląskich Dąbrówka Wielka niemal automatycznie kojarzy się z wyobrażeniem kobiet w stroju ludowym charakterystycznych dla Górnego Śląska (badania własne). Jest to jedno z miejsc na mapie Górnego Śląska (obok bytomskiego Rozbarku i świętochłowickich Lipin), w których tradycja noszenia stroju przetrwała najdłużej, a współcześnie jest świadomie wykorzystywana nie tylko dla samej promocji stroju rozbarskiego, ale także integracji społeczności lokalnej opisywanego obszaru. Konstrukcja ta nabiera realnego znaczenia za sprawą osób dysponujących sporą wiedzą odnośnie do konwencji, w jakich osadzony był tutejszy strój ludowy. Transponując tę wiedzę, świadomie wpływają one na postrzeganie miejscowego stroju ludowego jako nieustanie ewoluującego fenomenu kultury. Osoby te (nazywane dalej: animatorami/animatorkami) nie skupiają się jednak wyłącznie na obiekcie, jakim jest ta specyficzna forma odzieży (strój ludowy), ale - co znaczące - również na kształtowaniu pewnych postaw przejawianych względem paradnej (uroczystej, odświętnej) wersji tegoż stroju. Warto zaznaczyć, iż całościowo podejście to wpisuje się w zaproponowane przez Marka Krajewskiego pojęcie etnologii ubioru. Strój ludowy funkcjonujący w tym kontekście, choć postrzegany nadal jako tradycyjny, ze względu na odmienne realia życia społeczno-kulturowego swoich nosicieli możemy zatem współcześnie określić mianem neostroju (tradycyjnego w formie, jednak konotu-

w Bytomiu, Muzeum Historii Katowic, Muzeum Miejskiego w Zabrzu czy Muzeum Powstań Śląskich w Świętochłowicach (wybrane instytucje). W chwili, gdy etnografowie reprezentujący wspomniane placówki gromadzili zbiory, strój ludowy zanikał - był niemal nieuchwytny w terenie. Wyjątkiem była Dąbrówka Wielka, której mieszkańcy wciąż dysponowali licznymi artefaktami interesującymi badaczy stroju regionalnego, stad też jego szeroka reprezentacja w zbiorach muzealnych.

2 Stój rozbarski stanowi najbardziej rozpoznawalną reprezentację stroju ludowego ludności wschodniej części Górnego Śląska (nierozerwalnie związany jest z jego najsilniej uprzemysłowionym obszarem). W kilku odmianach zróżnicowanych pod względem zdobnictwa (nie zaś w samym typie) obejmował swym zasięgiem ziemię bytomską, raciborską oraz opolską. Stopniowo jednak pod wpływem różnych czynników zarysowało się bardziej widoczne zróżnicowanie poszczególnych elementów tych strojów (zob. Bazielich 2002: 29-32; Toboła-Feliks 2020: 186-187).

3 Współczesne działania promocyjne ułatwione są dzięki sieci Internet, w tym mediom społecznościowym (zob. np. https://www.facebook.com/dombrowkawielka, 7.01.2021).

${ }^{4}$ Konstrukcja słowna zainspirowana wykładem dr. Jarosława Eichstaedta zatytułowanym $Z$ muzealnego magazynu w teren, ale czy z powrotem? wygłoszonym w trakcie ogólnopolskiej konferencji naukowej 
jącego odmienne aniżeli pierwotnie funkcje). W artykule celowo jednak pozostanę przy nazewnictwie niepoprzedzonym przedrostkiem neo, choć nieco poszerzę rozumienie stroju ludowego. Ten w ujęciu historycznym postrzegać będę jako formę odświętnego i obrzędowego ubioru chłopskich warstw społeczeństwa ${ }^{5}$, mogącą wyrazić tożsamość w odniesieniu do regionu geograficznego lub danego okresu w przeszłości; wskazującą jednocześnie miejsce jednostki w systemie stratyfikacji społecznej, informującą o jej stanie cywilnym oraz nawiązującą do konkretnego wycinka roku liturgicznego tudzież obrzędowej roli nosiciela, wyróżniającą się szczególną formą detali zdobniczych oraz jakością tkanin, z których został uszyty (Biernacka 1976: 379). W kontekście współczesnym będę natomiast interpretować strój jako specyficzną formę kultywowania tradycji przodków, wykraczającą znacznie poza swe kanoniczne ramy (chodzi nie tylko o wierne odtworzenie pewnego wzorca, ale także wpływanie na swojego aktualnego/faktycznego nosiciela). Stanowi to zatem rodzaj estetycznej ekspresji wyrażającej potrzebę emanacji własnego ja, wyraźnego zaznaczenia swojej obecności na tle grupy własnej poprzez odgrywanie określonej roli, opartej na głęboko zakorzenionych wartościach, stanowiących niejako pomost pomiędzy teraźniejszością a dziedzictwem przodków. Jest to jednak strój pozbawiony autentycznej funkcji semantycznej czy też wierzeniowo-magicznej (ta ostatnia zostaje zastąpiona przez aspekt kreacyjno-ludyczny) ${ }^{6}$.

\section{Strój ludowy jako narzędzie integrowania grupy własnej}

Animacja środowisk lokalnych stanowi zagadnienie interdyscyplinarne. Ustalenie jej zwartej definicji wciąż pozostaje otwarte. Dydaktyka tego rodzaju polega na tworzeniu określonych postaw wobec tradycji. Składa się na nią zespół różnorakich elementów, wśród których wiodącą rolę pełnią aktywne metody edukacyjne, dające pole do popisu animatorom (edukatorom) przekładającym idee animacji na praktyczne współdziałanie z członkami określonej społeczności lokalnej. Rola animatora polega na pobudzaniu do działania - dawaniu pewnego impulsu. W określonych sytuacjach zdarza się, że impuls

$Z$ terenu do muzealnego magazynu. Metodologiczne wyzwania w badaniach odzieży tradycyjnej (organizatorzy: Polskie Towarzystwo Ludoznawcze - oddział w Lublinie, Sekcja Stroju Ludowego działająca przy ZG PTL, Muzeum Narodowe w Lublinie). Konferencja odbyła się 20 listopada 2020 roku na platformie Zoom.

5 Odniesienia do nosicieli stroju ludowego (chłopskiej warstwy społeczeństwa) wpłynęły na określanie go mianem chłopskiego (termin ten z języka potocznego przeniknął także do literatury naukowej, odnosząc się do kompletów paradnych, nie należy utożsamiać go zatem z odzieżą noszoną przez chłopów w dni powszednie). W tradycji śląskiej sformułowanie strój chtopski jest synonimicznie z określeniem strój ludowy, a same nosicielki stroju nazywa się wprost chopionami. Strój ten przede wszystkim wyróżniał chłopów na tle innych stanów, przy czym traktowanie stroju lub niektórych jego składników jako dobra majątkowego można odnieść głównie do tej grupy chłopów (gospodarzy), którzy posiadali środki na realizację takich potrzeb (Bittner-Szewczykowa 1976: 11).

6 Strój ludowy nie pozwala obecnie umiejscowić jednostki w strukturze społecznej. Nie odczytamy z niego zatem pozycji ekonomicznej właściciela czy też jego stanu cywilnego. 
ten płynie $\mathrm{z}$ wnętrza danej zbiorowości, wychodząc od osób, które niejako intuicyjnie i samozwańczo stają się animatorami. Działania te odnosząc się do założeń wyeksplikowanych przez Pierre'a Besnarda prowadzą nas do pojęcia performatyki (Jedlewska 2003: 60). Etykieta performansu, opuszczając swój matecznik - przestrzeń teatru, nie wykluczała odniesień do rapsodycznych narracji ludowych, nie dziwi zatem, iż z czasem perspektywa ta stała się preludium do wyodrębnienia nowego paradygmatu wiedzy ${ }^{7}$, a ukute przez Richarda Schechnera pojęcie zachowanego zachowania (Schechner 2006: 63) zaadaptowane na potrzeby regionalizmu stało się fundamentem tzw. zaangażowanej edukacji środowiskowej (McKenzie 2011: 9-10). Oczywiście prymat w tych rozważaniach nieustannie wiodą nawiązania do teorii wypracowanej przez Ervinga Goffmana (Goffman 2020: 45). Goffmanowski człowiek osadzony w sieci interakcji jest blisko spokrewniony z opisywanym przez egzystencjalistów człowiekiem wrzuconym w sytuacje. Na tak zarysowanym polu tradycja to iluzja konstruowana poprzez narrację, niewykluczającą znacznych wariantyzacji. Podejmowane działania określają kreowane oddolnie widowiska jako kulturę w dziataniu. Kluczowe są tu nie tylko postawy aktorów społecznych, ale także widzów, bowiem tylko wspólnie sprawiają oni, że rekonstrukcja ma sens. Stąd ich skuteczność każdorazowo warunkowana jest przez zaangażowanie (Skurzyńska 2013: 148). Podobne wytyczne waloryzuje zresztą także socjologiczna teoria ugruntowana Anselma Straussa, będąca metodologiczną podstawą koncepcji spotecznych światów. Rozumiemy ją jako zespół aktywności - primary activity ${ }^{8}$, powiązanych za pomocą sieci komunikacji (Strauss 1978: 122). Spoteczny świat stanowi pewne uniwersum, jest kulturowym obszarem, w ramach którego poruszają się i działają jego uczestnicy. To interaktywna, dynamiczna całość, skoncentrowana wokół centralnego działania, jakie podejmują członkowie danej grupy. To także nieustannie tocząca się dyskusja na temat tego, jakie warunki normatywne powinny być spełnione, aby można było podjęte działania uznać za właściwe i zrealizowane tak jak należy. Osoba przyjmująca rolę animatora z jednej strony staje się więc organizatorem swych indywidualnych poczynań (względnie najbliższego otoczenia - członków rodziny), z drugiej zaś pełni rolę głównego mechanizmu organizującego życie społeczne większej zbiorowości (Clarke 1991: 131). Symulacja ekspresji kulturowej, jaka dokonuje się w trakcie przedsięwzięć animacyjnych, wyróżnia się wymiarem kreacyjnym (Białkowski 2008: 12). Działania animacji zaangażowanej

\footnotetext{
Zgodnie z metodologiczną koncepcją Tomasza Kubikowskiego mowa o performatyce stanowiącej określenie komplementarne względem wiedzy o widowisku (Kubikowski 2006: 392). Uosabia ona projekt interdyscyplinarnych studiów nad widowiskami obecnymi zarówno w kulturze, jak i w świecie społecznym (Skórzyńska 2008: 31-45). Performance Studies nie mają jeszcze swojego miejsca w polskiej strukturze akademickiej, jednak antropologia widowisk czy wiedza o widowisku są już przedmiotami wykładowymi, głównie w ramach kulturoznawstwa. Akademicki status antropologii widowisk promowany jest przez środowisko wrocławskich kulturoznawców na czele z Leszkiem Kolankiewiczem oraz Wojciechem Dudzikiem (zob. Kolankiewicz 2010).

8 W niektórych tekstach spotyka się też określenie core activity (Strauss 1993: 216).
} 
w tym przypadku zamykają się w nurcie retrospekcji. Nauczanie retrospektywne stanowi pochodną metody symulacyjnej, która wdraża do analizy zagadnień, będących niegdyś realnymi problemami tudzież wartościami. Dlatego też aspiracją działań skupionych na popularyzacji piękna oraz różnorodności regionalnego stroju ludowego staje się kształtowanie poczucia odpowiedzialności za pielęgnowanie tradycji ${ }^{9}$. Pośrednio formatowanie tego rodzaju więzi może wpływać na przykład na penetrowanie zaułków rodzinnej mikro-historii współczesnych nosicieli stroju. Warunkiem zakorzenienia określonych wartości jest tu przekaz budowany na fundamencie emocji, a te potęgowane są przez poczucie swego rodzaju metaforycznego przesunięcia w czasie.

Performatywność to zatem pewien napęd kultury. Osoby starające się zachować tradycję noszenia stroju ludowego oraz transponowania jej dalej doskonale zdają sobie z tego sprawę. Znają konteksty swojej działalności, mając równocześnie świadomość, iż aktywizacja grupy własnej jest w określonym stopniu potęgowana poprzez zainteresowanie płynące $\mathrm{z}$ zewnętrz ${ }^{10}$. To jednak jest tak naprawdę drugorzędne, na pierwszy plan wysuwa się bowiem zagadnienie odnoszące się do przeszłości stroju regionalnego. W tym kontekście Milton Singer mówi o żywych przekaznikach, funkcjonujących w ramach struktury określanej mianem widowisk kulturowych (Dudzik 2009:16; Dziadowiec 2011: 63). Widowiska te to nie tylko celowo zaaranżowane sytuacje (ludyczne formy rozrywki), ale także wycinki życia konkretnej społeczności zogniskowane przede wszystkim wokół ważnych wydarzeń o znamionach religijnych (z taką właśnie sytuacją mamy do czynienia w przypadku Dąbrówki Wielkiej). Współcześnie wychodzą one poza obszar tradycyjnie przypisanych im kontekstów kulturowych, co wpływa na zacieranie się granic istniejących między praktykami, które tradycyjnie związane były z tzw. życiem poważnym. Tworzy to nośnik treści dydaktycznych zaznajamiających $z$ artefaktami kulturowymi istotnymi z historycznego lub historyczno-sentymentalnego punktu widzenia. Symulacja ekspresji kulturowej,jaka dokonuje się w trakcie przedsięwzięć skupionych wokół procesu aktywnego przekazywania treści zogniskowanych wokół stroju ludowego wyróżnia się wymiarem kreacyjnym, rozumianym jako konglomerat działań stymulujących indywidualne adaptowanie niesionych treści (Białkowski 2008: 11-12). Należy przy tym mieć na uwadze, iż rzeczywistość postrzegana przez nas jako obiektywna, każdorazowo przesycona jest emocjami i wyobrażeniami naznaczonymi subiektywnie.

\footnotetext{
${ }^{9}$ Dążenia te jednoznacznie wyrażają osoby zajmujące się propagowaniem tradycji zakładania stroju ludowego (badania własne).

${ }^{10}$ Uroczystości, w trakcie których mieszkańcy Dąbrówki Wielkie występują w strojach ludowych typowych dla tradycji rozbarskiej, przyciągają sporo osób spoza miejscowości. Działania te odgrywają istotne miejsce w analizach etnologicznych (np. Lysko, Garstka 2018: 236-237), są one także intensywnie promowane na licznych niezależnych stronach internetowych dotyczących folkloru (zob. http://www.dwonline.pl/ bozecialo2016.html, 11.12.2020 (link zarchiwizowany); https://dabrowkawielka.pl/Zdjecia, 13.12.2020) bądź mediach społecznościowych należących do osób zakładających strój ludowy, są one więc promowane wielotorowo.
} 
Wrażenie realności konstytuuje tu odniesienie do pewnych atrybutów czasu minionego (w tym wypadku konkretnej formy stroju ludowego). Rozbudzenie treści poznawczych, ale przede wszystkim integrowanie społeczności wokół konkretnych wartości skupionych niczym w soczewce w elementach kształtujących ostateczny wizerunek stroju regionalnego, pozwala na spojrzenie na niego zupełnie z innej perspektywy. Cel działań podejmowanych pod szyldem tak prowadzonego aktywnego podejścia do tradycji należy rozumieć jako ciąg zadań wpływających na kształtowanie zasobów intelektualnych społeczności lokalnej. Można powiedzieć, że założenia animacji zaangażowanej służą za pewien drogowskaz metodologiczny. Kontakt z artefaktem (strojem ludowym), który zwyczajowo kojarzy się jedynie z martwym eksponatem wpisanym w przestrzeń ekspozycji muzealnej doprowadza do wzmocnienia potencjału lokalnego kapitału społecznego. W tym miejscu analiza pola działania społecznego potrzebuje jednak szczególnej umiejętności etnograficznego rozumienia kultury (Malewska-Szałygin 2008: 29-31). Etnograf oraz kulturoznawca Paul Willis wskazuje, że jest to coś więcej niż tylko kwestia rozpoznania procesów dających się obserwować z zewnątrz (Willis 2005: 28-35). Istotna jest tu swego rodzaju metodologiczna „zębatka”, która napędza wiedzę o kulturowych wymiarach istnienia spotecznego świata, wypełniającego pole zarezerwowane dla performatywności. To, co etnograficznie zakorzenia i ustala całe spektrum wyobrażonych znaczeń w obrębie myśli społecznej (Pilińska, Rakowski 2009, 35). Samoorganizacja staje się więc miejscem, w którym powstaje przestrzeń dla specyficznie pojmowanej społecznej twórczości zbiorowej, wymagającej etnograficznej wyobraźni oraz działań, które określić możemy mianem etnograficzno-animacyjnych (Mencwel 2006: 48). Buduje to mechanizm odpowiedzialny za transmisję tradycji (tu konkretnie: tradycji noszenia stroju ludowego). W tym sensie badany teren wraz z badaną społecznością jest rozumiany raczej jako ciąg wydarzeń, percepcji oraz interakcji.

\section{Specyfika Dąbrówki Wielkiej}

Historia Dąbrówki Wielkiej (dziś dzielnicy Piekar Śląskich) sięga XII wieku (Jaros, Minkus 1969: 555). Wieś Dąbrówka, nazywana później Wielką, do 1323 roku jako część ziemi bytomskiej stanowiła własność książęcą (Kuczob 2001: 22-23). Już wówczas we wsi istniał młyn (Długosz 1470: 431), co świadczyło o względnej zamożności jej mieszkańców. Miejscowości nie ominęły różne perturbacje historyczne, jednak począwszy od XVI wieku (po nabyciu wsi przez miasto Bytom) ta stopniowo przekształcała się z miejscowości typowo rolniczej w ośrodek górnictwa (ołowiu i cynku, później węgla kamiennego), co było istotne dla jej rozwoju ${ }^{11}$. Ludność wiejska okolic

\footnotetext{
${ }^{11}$ Industrializacja wpłynęła znacznie na wzrost zamożności ludności - mieszkańcy Dąbrówki Wielkiej mogli kupować kosztowne elementy paradnego stroju bytomskiego. Wysoki status ekonomiczny wsi, widoczny w bogactwie zdobień i różnorodności miejscowego stroju ludowego, znajduje dziś odzwierciedlenie w wielu kolekcjach muzealnych.
} 
Bytomia wykazywała wówczas relatywną jednolitość pod względem zakładanych kompletów odzieży paradnej oraz kultywowanych zwyczajów, co pozwala przypuszczać, iż była ona w niewielkim stopniu zróżnicowana narodowościowo (Dąbrówkę Wielką podobnie jak sąsiadujące $\mathrm{z}$ nią wsie zamieszkiwali głównie osadnicy pochodzenia polskiego). Omawiany teren charakteryzuje tradycja noszenia stroju regionalnego określanego w nomenklaturze fachowej mianem stroju rozbarskiego ${ }^{12}$. W początkach XX wieku ta tradycja stopniowo zanikała, wypierana przez tańszy, bardziej praktyczny strój miejski. Pojawiające się wówczas działania mające na celu ożywienie folkloru bytomskiego (takie jak na przykład Oberschlesien Trachtenfeste), promowane przez ówczesnego właściciela i zarządcę tego obszaru - księcia Henckel von Donnersmarck ${ }^{13}$, spotykały się z umiarkowanym odzewem miejscowych (Kuczob 2001: 78). Zwyczaj chodzenia w stroju ludowym nigdy jednak nie został we wsi w pełni zarzucony. Współcześnie Dąbrówka Wielka jest miejscowością szczególną na mapie Górnego Śląska, która nie straciła swego pierwotnego charakteru. Mimo znamiennego wiązania miejscowej ludności z przemysłem wydobywczym oraz późniejszego wchłonięcia Dąbrówki Wielkiej w granice administracyjne Piekar Śląskich, ta nadal zdaje się być autonomicznym obszarem o wyraźnych znamionach osady wiejskiej. Wrażenie to niewątpliwie potęguje przywiązanie miejscowej ludności do tradycji noszenia stroju chłopskiego ${ }^{14}$, o czym szerzej poniżej.

\section{Animacja zaangażowana w zachowaniu stroju ludowego. Analiza badań własnych}

Badania pilotażowe dotyczące stroju ludowego w Dąbrówce Wielkiej wykazały, że tradycja zakładania elementów charakterystycznych dla dawnego ubioru paradnego chłopskich warstw społeczeństwa jest wciąż żywa. Mieszkańcy tej miejscowości są mocno zaangażowani w aktywną promocję stroju odświętnego swoich przodków. Działania podejmowane na terenie Dąbrówki Wielkiej można określić mianem specyficznej rewitalizacji stroju regionalnego (łac. re vita - ożywianie), gdyż są one koordynowane przez lokalnych animatorów i mają na celu zmianę sposobu myślenia o lokalnym stroju ludowym. $\mathrm{Na}$ opisywanym obszarze strój zachował swoją autentyczność (przez co jest

${ }^{12}$ Nazwa pochodzi od wsi Rozbark (niem. Rosenberg), stanowiącej dzielnicę Bytomia, stąd strój zamiennie bywa nazywany bytomskim (Piskorz-Branekova 2008: 158-165). Oba określenia funkcjonują w literaturze przedmiotu jako synonimiczne (Bazielich 2017: 165-180).

${ }^{13}$ Książe Guidotto Henckel von Donnersmarck wraz z małżonką Anną starał się propagować rodzime stroje ludowe; sam często zakładał strój rozbarski. W efekcie jego działań w Orzechu oraz Kozłowej Górze powstały Towarzystwa Opieki na Strojem Ludowym, jednak zasięg działalności tych organizacji wykraczał znacznie dalej. W styczniu 1910 roku urządzono pierwszy kiermasz strojów ludowych (Grabowski 1935: 113-114; Bazielich 2002: 31; Kuzio-Podrudzki 2003: 119).

${ }^{14}$ Mieszkańcy Piekar w pewnym stopniu kultywują również zwyczaj noszenia stroju śląskiego (podobnie zresztą jak okolicznych miast - Bytomia, Chorzowa czy poszczególnych dzielnic Katowic), ale areał tych działań wydaje się mniej znaczący. 
wyjątkowym obiektem badawczym), odmiennie niż w wielu ościennych miejscowościach, gdzie stracił on swoją pierwotną funkcję tożsamościową (budowanie poczucia przynależności regionalnej lub mikroregionalnej) oraz semiotyczną (kreślącą cechy tożsame dla konkretnego nosiciela, choć dziś w nieporównywalnie mniejszym stopniu, iż miało to miejsce historycznie), stając się jedynie estradowym kostiumem wykorzystywanym przez grupy folklorystyczne.

W tej części artykułu dokonam analizy materiałów z badań własnych prowadzonych na terenie Dąbrówki Wielkiej w latach 2018-2019 (ze względu na sytuację pandemiczną ograniczyłam je w roku 2020). Proces badawczy obejmował spotkania (wywiady) z autochtonkami mieszkającymi w badanej dzielnicy Piekar Śląskich. Narratorki dzieliły się ze mną swoimi opowieściami rodzinnymi, jednocześnie przekazując mi wiedzę dotyczącą stroju ludowego: miejscowych nazw zwyczajowych poszczególnych elementów stroju rozbarskiego, sposobu ich poprawnego zakładania (kolejność, dopasowanie stosowne do okazji itp.) i odtwarzania poszczególnych części stroju paradnego (chodziło głównie o galandy, ale też rekonstrukcję uszkodzonych ewenementów stroju). Respondentki pozyskiwały te informacje drogą dziedziczenia od miejscowych chopion (kobiet noszących strój ludowy na co dzień, często z nimi spokrewnionych). W trakcie wspomnianych spotkań sama zostałam ubrana w strój ludowy charakterystyczny dla rozbarskiej druhny ${ }^{15}$, co pozwoliło mi pełniej wniknąć w badany świat spoteczny oraz poszerzyć materiał o wnioski pochodzące z obserwacji uczestniczącej.

${ }^{15}$ Materiał ten został zarejestrowany w formie wideo. Szacunek, z jakim podchodzono do poszczególnych elementów stroju paradnego szczególnie dobrze odzwierciedla sposób zakładania galandy (najbardziej wyróżniający się atrybut rozbarskiego stroju kobiety niezamężnej). Jedna z informatorek (K, ur. 1964) podała: włosy pod galandq musiały być gładko uczesane, najlepiej lekko tłuste. Dzielono je na dwie części na wysokości potylicy i zawiązywano białą wstążką. Następnie każdą z części owijano szczelnie tworząc tzw. okręcke, która docelowo wystawała spod galandy, z tego powodu na białą wstążkę spodnią okręcano dodatkowo jasnoróżową szeroką szlajfe wiązaną na końcu, aby całość mocno się trzymała. Czynność tę powtarzano z obu stron. Okręcka szła przy uszach ani nie za wysoko, ani nie za nisko, aby galanda była osadzona w odpowiednim miejscu. Zawiązywano ją mocno nad czołem, potem przeciągano z powrotem i wiązywano z tyłu. Następnie brano tzw. koniec (poza Dąbrówką Wielką w powszechnym użyciu występuje określenie harazionka), czyli prostokątny kawałek materiału w kolorze czerwonym z granatowym wykończeniem (urbinkiem - wciętym w ząbki kawałkiem granatowego sukna wystającym nieznacznie spod harazionki). Koniec przykładano szczelnie do czoła na okręcke, której górna krawędź powinna być widoczna. Jeśli koniec był zbyt szeroki, podwijano go, aby zachować odpowiednie proporcje. Następnie wiązano z tyłu głowy, a wystające sznurki chowano pod okręcę. W kolejnym etapie zapinano tzw. klapy wykonane $z$ harmonijnie ułożonych siedmiu warstw kolorowych wstążek. Pierwsza $z$ nich mocno wykrochmalona, biała, wyszywana była haftem dziurkowanym. Poszczególne warstwy musiały widocznie odstawać na boki. Na to dopiero przychodziła galanda, w której z przodu tradycyjnie umiejscowiona była na środku czerwona róża. Nie stanowiła ona zwartego wieńca, zrobiona była na gąbce przytwierdzonej do drutu, który zwijany był na kształt wianka z tyłu głowy. Całości dopełniał wionuszek (niewielki wianuszek) zapinany za pomocą harnadli (rodzaju wsuwek) z tyłu nad wspomnianym łączeniem galandy oraz dwa $\dot{z}$ ḋadetka (małe okrągłe lusterka, ujęte w ozdobną blaszkę). Jedno zapinane w środku wionuszku na wysokości harnadli, drugie na dole pod galarda, aby zasłonić łączenie klap (zob. fot. 1-3). 
Z przeprowadzonych przeze mnie badań wynika, iż w paradnej wersji stroju kobiecego noszonego w Dąbrówce Wielkiej tradycyjnie zakładano cztery spódnice, choć czasem ich liczba wzrastała do pięciu za sprawą tzw. wilurki. Zwyczajowo ubierano pikowaną watórwkę szytą z inletu, kretonkę, biały płócienny spodek zdobiony haftem płaskim oraz tzw. zogibkami (było ich jedenaście) i wreszcie wierzchnią suto marszczoną w pasie, plisowaną kieckę. Im zamożniejsza kobieta, tym spódnica (kiecka) była rzą́niej$s z a$ (bardziej okazała $)^{16}$. Wełnę na kiecki, podobnie jak wiele innych elementów stroju, nabywano w Bytomiu ${ }^{17}$. Istotny element stroju stanowiła aksamitna, adamaszkowa lub szyta z jedwabiu jakla zdobiona na obrzeżach gęmbkq (gipiurą produkcji fabrycznej) o powtarzających się motywach florystycznych. Całości dopełniał fortuch ${ }^{18}$ wykonany z chińskiego jedwabiu oraz zależnie od pogody i pory roku szpigiel lub szpigielek (chusta naramienna/nagłowna) z kaszmiru tureckiego. Forma i kolorystyka stroju ściśle korespondowała $\mathrm{z}$ rokiem liturgicznym. Poszczególne święta kościelne wymuszały określony wygląd stroju paradnego, choć również niedziele zwykłe nie pozostawały bez znaczenia ${ }^{19}$. Cechą charakterystyczną stroju noszonego na terenie Dąbrówki Wielkiej było wywijanie ku górze koronkowych krez zdobiących rękawy kabatka oraz specyficzne układanie krezy tworzącej jego kołnierz (dotyczy to ubioru obrzędowego kobiet niezamężnych) ${ }^{20}$. Znamienny był również stopień wyszkrobienia (wykrochmalenia) spódnic spodnich (obecnie powiedzielibyśmy - halek), co wpływało na wyjątkową objętość damskiej sylwetki. Za najbardziej uroczysty uchodził ancug, czyli jakla, zwykle w czarnym kolorze, oraz korespondująca z nią kiecka (tworzące komplet).

Obecnie strój regionalny zakładany jest przez mieszkańców Dąbrówki Wielkiej przy wielu okazjach. W większej skali możemy go podziwiać podczas odpustu parafialnego ${ }^{21}$, procesji Bożego Ciała czy uroczystościach związanych ze świętem plonów. Miejscowe stroje ludowe noszą osoby w różnym wieku (w tym wielu młodych ludzi,

${ }^{16} \mathrm{~W}$ stroju rozbarskim spore znaczenie przypisywano obfitości kobiecej sylwetki. Mieszkanki Dąbrówki Wielkiej znane były szczególnie z zamiłowania do podkreślania znacznej kopiastości kiecki.

${ }^{17}$ Zdaniem informatorek najczęściej nabywano je w sklepie $u$ Betkowej.

${ }^{18}$ Określenie fortuch (fartuch) dotyczyło paradnej formy zapaski (badania własne; potwierdzone również w literaturze przedmiotu, zob. Bazielich 1976: 6).

${ }^{19}$ W Dąbrówce Wielkiej w pierwszą niedzielę miesiąca zakładano zwyczajowo różową kieckę; czarną, jedwabną jakle i biały lub niebieski fortuch. W kolejną niedzielę pojawiała się obowiązkowo zielona lub siandarsko (turkusowa) kiecka, ponownie czarna jakla oraz fortuch - tym razem utrzymany w żółtej gamie kolorystycznej. Całości dopełniał szpigielek z tzw. nerkq we wzorze. W ostatnie dwie niedziele kiecka miała zwykle kolor czekoladowy (choć dopuszczalny był także odcień określany jako błękit królewski), jakla bez zmian (czarna), ponadto haftowany maszynowo fortuch. W Wielkim Poście i Adwencie analogicznie jak na pozostałych obszarach zasięgu stroju rozbarskiego obowiązywał strój żałobny. Podobnie podczas wielkich uroczystości kościelnych wygląd oraz kolorystyka paradnej odzieży chłopskiej nie odbiegała znacznie od innych miejscowości, w których zakładano ten rodzaj stroju.

${ }^{20}$ Tzw. strój do wierzchnia charakterystyczny dla druhny.

${ }^{21}$ Wspomnienie Matki Boskiej Wspomożenia Wiernych przypadające w drugiej połowie maja (zob. https://www.dabrowkaparafia.wiara.org.pl). 

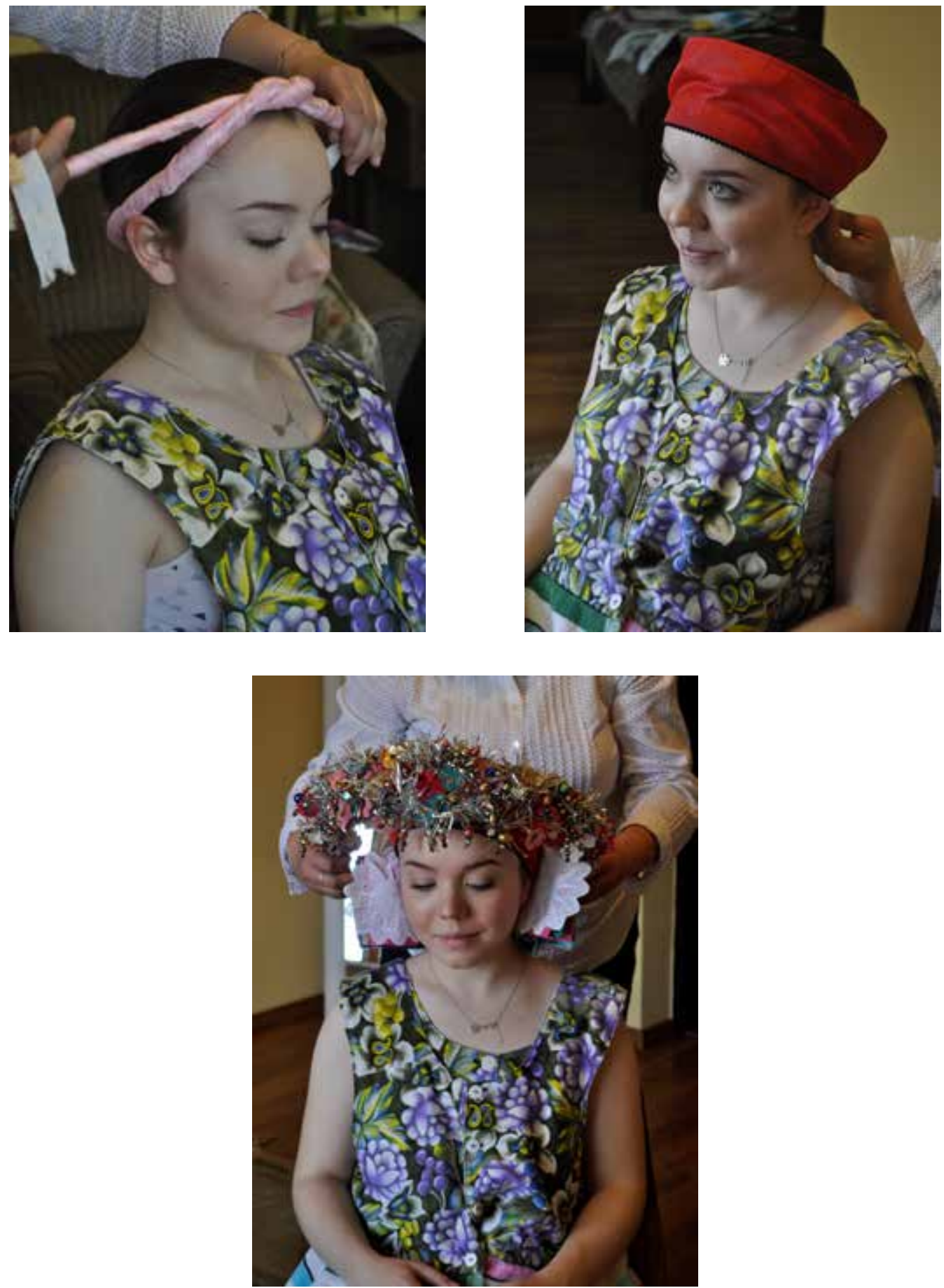

Fot. 1-3. Kolejne etapy zakładania galandy, najbardziej zdobnego elementu rozbarskiego stroju panny, Dąbrówka Wielka, fot. M. Toboła-Feliks 2019 
szczególnie dziewczęta). Często stroje te nie są ich własnością - są użyczane przez osoby krzewiące pamięć o tradycji noszenia stroju chłopskiego, kultywujące tajniki jego prawidłowego zakładania (przekazywane z pokolenia na pokolenie). Są to kobiety (zwykle rodowite dąbrowianki) nie tylko ubierające innych w stroje ludowe (jakimi dysponują w swych prywatnych kolekcjach), ale - co istotne - pełniące role samozwańczych animatorów miejscowej społeczności. Do grupy tej należą między innymi Beata Prudło (zob. fot. 4-5), Danuta Szczogiel czy Teresa Ogłodek (to jedynie wybrane postacie aktywnie zaangażowane $\mathrm{w}$ promowanie miejscowego stroju ${ }^{22}$. Tworzą one grupę współpracujących osób zachęcających swoich sąsiadów (szczególnie osoby młode) do zaangażowania się w życie lokalnej społeczności, przejawiające się głównie w aktywnym uczestnictwie (koniecznie w stroju ludowym) w różnego rodzaju uroczystościach, w przeszłości niezwykle ważnych z punktu widzenia społeczności wiejskiej (głównie kościelnych). Animatorki doskonale zdają sobie sprawę, iż te działania w odpowiedni sposób rozpropagowane (za sprawą tzw. marketingu szeptanego, ale także dzięki szerokiemu zasięgowi mediów społecznościowych) są doskonałą promocją Dąbrówki Wielkiej. Uzasadnieniem tego rodzaju działań jest spore zainteresowanie strojem ludowym, widoczne nie tylko ze strony badaczy (etnologów i folklorystów) czy lokalnych pasjonatów historii, ale też często przypadkowych osób, zauroczonych wyglądem miejscowego stroju ludowego.

Animatorki świadomie wyszukują osoby, które założą strój ludowy (w tym celu zachęcają i motywują swoje otoczenie, czyniąc to nie tylko poprzez rozmowy, ale też prezentację szczególnie bogatych elementów stroju); te $\mathrm{z}$ reguły namawiają w swoim środowisku kolejne - na zasadzie kuli śniegowej. Finalnie organizują grupy takich osób, ubierając je w strój z przestrzeganiem zasad prawidłowego, „uświęconego tradycją”, sposobu zakładania jego poszczególnych elementów. Korzystają ze strojów znajdujących się $\mathrm{w}$ ich prywatnych zbiorach, stanowiących rodzinne pamiątki lub elementy strojów ludowych nabywane od innych mieszkańców Dąbrówki celem uratowania ich przed wyrzuceniem. W prowadzonych działaniach dokładają wszelkich starań, aby stroje pochodzące $\mathrm{z}$ tego terenu nie były już sprzedawane do muzeów bądź prywatnych kolekcji (co było szczególnie widoczne na przełomie lat 80. i 90. XX wieku²3; współcześnie

${ }^{22}$ Działania wymienionych osób nie ograniczają się jedynie do ubierania innych mieszkańców Dąbrówki Wielkiej w stroje paradne $\mathrm{z}$ okazji dużych uroczystości kościelnych, takich jak odpust parafialny, Boże Ciało, stanowa pielgrzymka kobiet do Piekar czy na Górę św. Anny oraz uroczystości dożynkowe. Kobiety te udzielają się także aktywnie w projektach tworzonych pod patronatem wielu instytucji, np. projekt: Purpurka na Polkę Regionalnego Instytutu Kultury w Katowicach (dziś: Instytut Myśli Polskiej im. Wojciecha Korfantego) lub warsztaty towarzyszące ogólnopolskiej konferencji naukowej Zdobnictwo stroju ludowego. Między rzemiostem i sztukq (Muzeum Górnośląski Park Etnograficzny w Chorzowie, 16-17 czerwca 2016 r.). Ponadto wygłaszają one liczne prelekcje i organizują warsztaty w Miejskich Domach Kultury, bibliotekach oraz muzeach (np. warsztaty malowania wstążek towarzyszące Nocy muzeów 2014, Muzeum Historii Katowic, zob. https://slaskie.naszemiasto.p1/noc-muzeow-2014-w-katowicach-bezplatny-bus-i-zwiedzanie/ar/c13-2719828, 7.01.2021).

${ }^{23}$ Zob. przypis 1. 

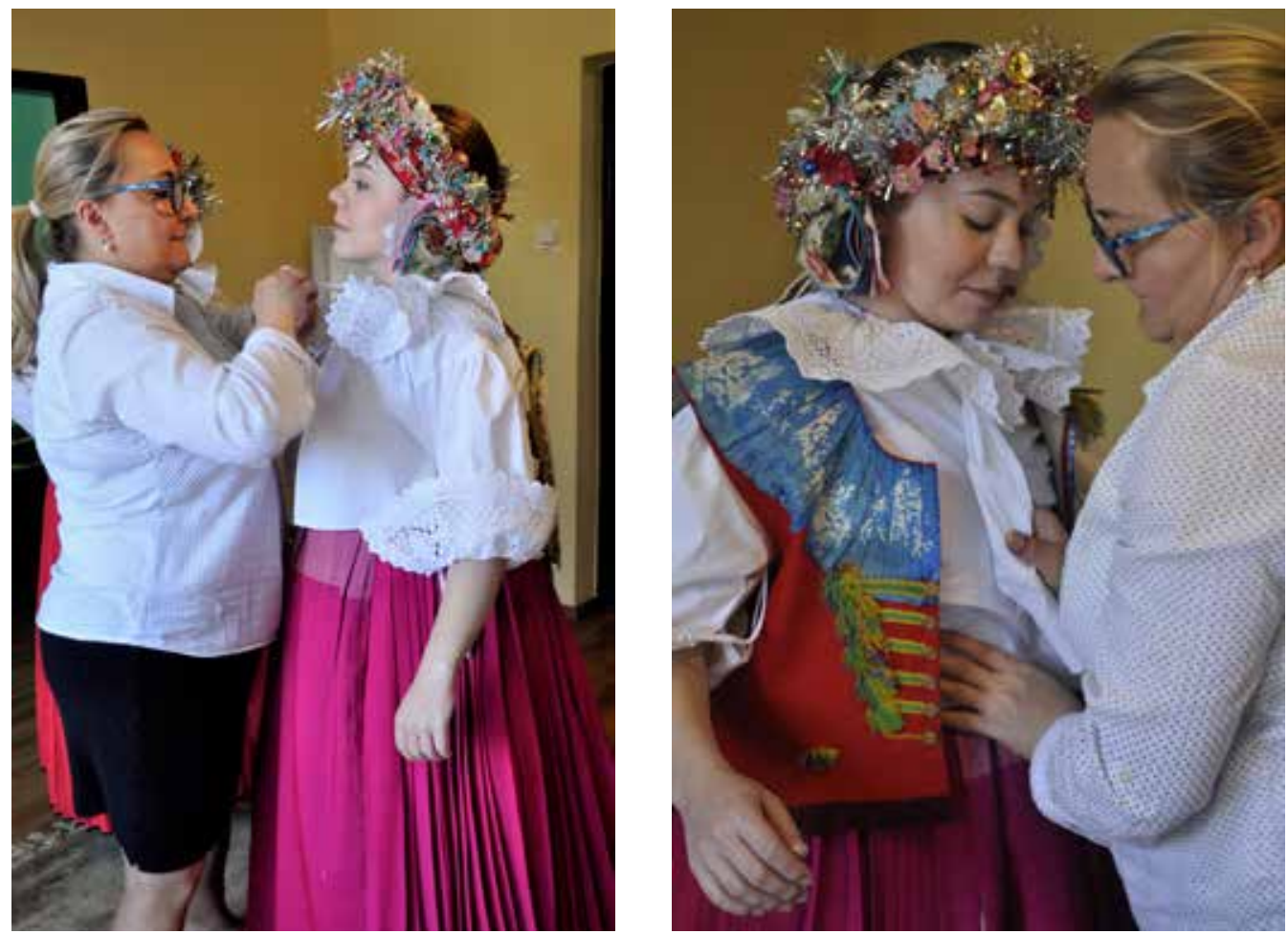

Fot. 4-5. Beata Prudło przygotowująca młode mieszkanki Dąbrówki Wielkiej do uroczystości odpustowych, Dąbrówka Wielka, fot. M. Toboła-Feliks 2019

odbywa się w mniejszej skali). Animatorki podejmują również działania zmierzające do renowacji bądź rekonstrukcji uszkodzonych fragmentów strojów, kierując się przy tym nie tylko własną wiedzą (choć ta jest dla nich głównym odnośnikiem), ale często konsultując te kwestie również z etnologami zajmującymi się badaniami odzieży tradycyjnej. Współpraca na linii muzea (działy etnograficzne/etnologiczne) - animatorki przebiega dwutorowo (przykładem mogą być między innymi efekty prowadzonych przeze mnie badań). Teresa Ogłodek zajmuje się dodatkowo odtwarzaniem tradycyjnych nakryć głowy kobiet niezamężnych - galand. Współcześnie nie ma już możliwości kontaktu z tzw. galandziarkami, zatem zachowanie zasad, jakimi się one kierowały wydaje się niezwykle istotne $^{24}$. Znaczące jest również to, że w trakcie zakładania stroju ludowego konkretnej osobie (szczególnie po raz pierwszy) animatorki opowiadają o tym, co robią w danej chwili i jakie ma to znaczenie dla finalnego wyglądu osoby ubieranej. Instruują jak należy zachowywać się i poruszać w stroju ludowym (na przykład jak usiąść w kiecce, aby plisy nie uszkodziły się przez przygniecenie). Te werbalne wskazówki edukacyjne są

${ }^{24}$ To zagadnienie poszerzę w trakcie dalszych badań. 
niezwykle istotne dla transmisji tradycji. Składają się one na jedno z podstawowych założeń animacji zaangażowanej, stanowiąc odzwierciedlenie aktywnych metod edukacyjnych. Animatorki podkreślają potrzebę zajmowania się tradycją związaną ze strojami ludowymi, szczególnie jej ginącymi aspektami (np. wspomniana technika wytwarzania galand). W pewnym stopniu świadomie nobilitują się, widząc w sobie depozytariuszki wiedzy minionych pokoleń, predestynowane do transponowania owej wiedzy dalej, dostrzegając w niej olbrzymią wartość dla konsolidacji lokalnego środowiska. Wspomniana silna identyfikacja ze społecznością lokalną dodatkowo uwiarygodnia ich działania, przez co spaja spoteczny świat odzwierciedlający poziom ich zaangażowania. Tym samym animatorki świadomie bądź też mimowolnie kładą fundament, na którym następnie inne osoby uczestniczące $\mathrm{w}$ działaniach stworzonego przez nie spotecznego świata, $\mathrm{w}$ zależności od swoich indywidualnych predyspozycji oraz predylekcji, nadbudowują dalsze zasoby kształtujące współczesną tożsamość regionalną. To właśnie te działania sprawiły, że strój ludowy stał się punktem wyróżniającym mieszkańców Dąbrówki Wielkiej na tle okolicznych miejscowości. Zwykle przed ubieraniem przewidzianym na przykład w dniu odpustu czy innej uroczystości odbywają się przymiarki, w trakcie, których dopasowuje się stroje do odpowiednich osób, dbając o to, by kiecki miały prawidłową długość,
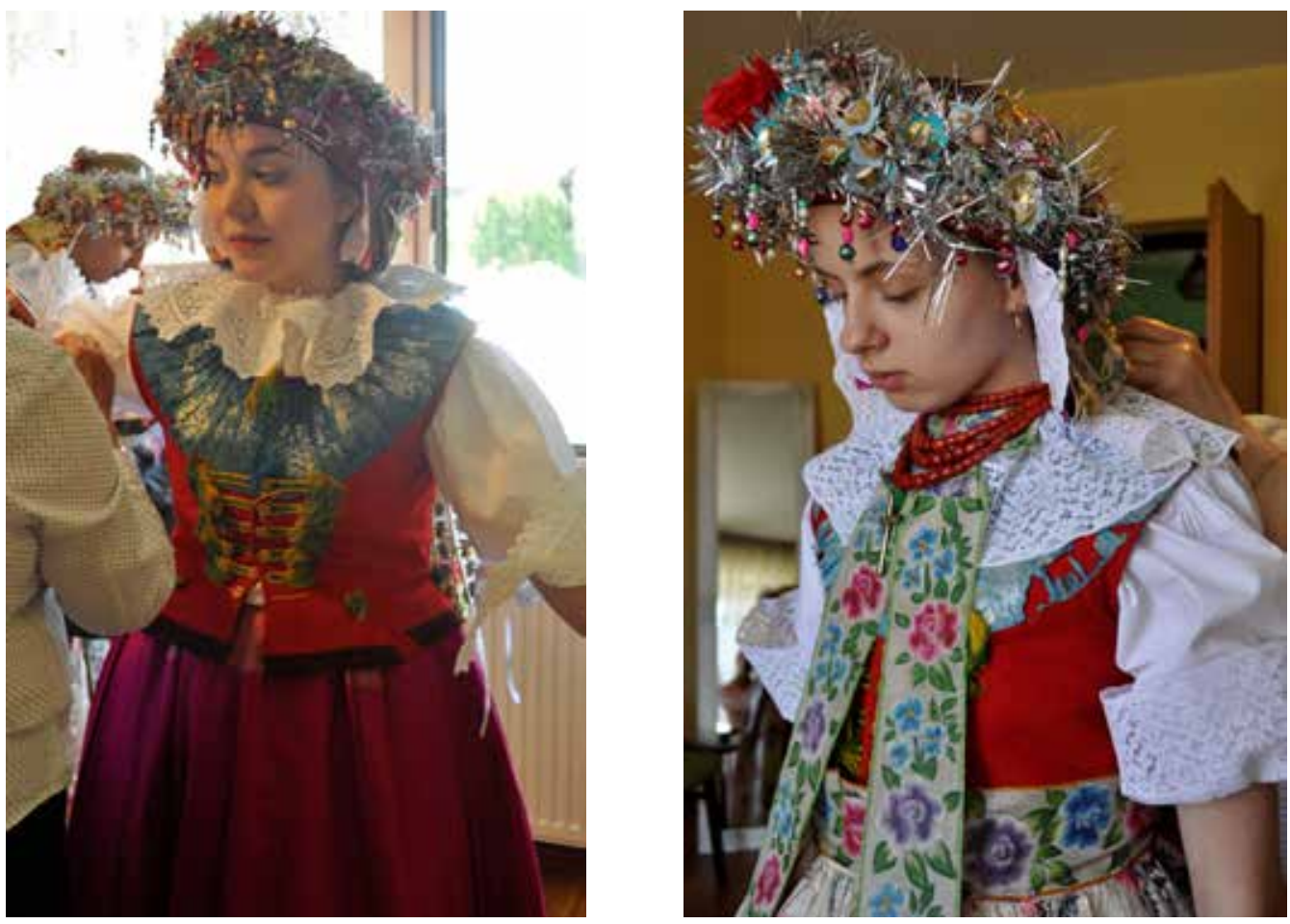

Fot. 6-7. Ubieranie w strój ludowy przed uroczystą procesją sumy odpustowej, Dąbrówka Wielka, fot. M. Toboła-Feliks 2019 
krawędzie spodków nie były spod nich widoczne, a wymiar fartucha odpowiednio korelował z długością kiecki. Wszystkie te działania mają na celu kultywowanie tradycji noszenia lokalnego stroju ludowego - nie jest to, zatem bezmyślne przebieranie się.

\section{Podsumowanie - wnioski z badań}

Sposób patrzenia na strój ulega głębokim przeobrażeniom, co rodzi nowe perspektywy badawcze. Konieczna wydaje się pogłębiona analiza tej problematyki, mająca na celu uzupełnienie powstałej luki poznawczej i zmianę w podejściu do pozornie skostniałej formy stroju ludowego. Istotne staje się odczytanie sensu tego rodzaju rekonstrukcji historycznych tworzonych z udziałem stroju ludowego. Stąd staram się zwrócić uwagę na nowe perspektywy analityczne związane $\mathrm{z}$ dokumentacją współczesnej wiedzy na temat twórców i odtwórców rekonstruujących stroje ludowe charakterystyczne dla Górnego Sląska, w tym głównie osób zajmujących się animacją zaangażowaną środowisk lokalnych.

Animacja zaangażowana posiada swój wymiar praktyczny, redefiniuje potrzebę identyfikacji jednostki (Godlewski 2002: 65). Z prowadzonych przeze mnie badań wynika, że dzięki inicjatywie animatora, który swoimi działaniami niejako inscenizuje (performuje) przeszłość, otwiera się także przestrzeń dla krytycznego myślenia (wnioskowania). Przeprowadzone analizy wskazują, że w przypadku osób noszących współcześnie strój ludowy kształtuje się zupełnie nowe spojrzenie, każące traktować tradycyjne stroje regionalne jako artefakt nacechowany autentyczną wartością, istotną także z współczesnego punktu widzenia. Animacja zaangażowana prowadzona przez osoby zajmujące się strojem ludowym, ale jednocześnie będące częścią danej zbiorowości lokalnej sprawiła, że nauczanie przestało być tylko arbitralnym przekazywaniem wiedzy o stroju. Konsekwencją tego jest także nowe pole działań otwierające się przed badaczami (np. etnologami oraz antropologami kultury). Ich celem jest współcześnie nie tylko gromadzenie danych o pozostałościach archaicznej kultury określanej dzisiaj mianem kultury typu ludowego, ale przede wszystkim analiza i charakterystyka zmian, jakie zachodzą w jej strukturze. Ponadto uchwycenie dalszej transmisji zmieniających się treści kultury, będących niejako kolejnym krokiem, wyższym poziomem w drodze do zachowania tradycyjnych wartości. Owa transmisja odbywa się poprzez zaangażowanie społeczności lokalnej. Nie jest to oczywiście w żadnym przypadku próba zamrożenia czasu i powrotu do dawnych tradycji czy obyczajów; istotą kultury jest przecież proces nieustannej przemiany - kluczowym dążeniem jest tutaj raczej to, by za sprawą umiejętnie prowadzonego procesu zarażania kultura stworzyć podwaliny dla kreacyjnego samorozwoju jednostki. To właśnie obserwujemy współcześnie na terenie Dąbrówki Wielkiej. Analizując rozmowy z osobami uczestniczącymi w przedsięwzięciach zainicjowanych przez animatorki, dostrzegam budowanie przez nie poczucia odpowiedzialności za zachowanie tradycji. Stanowi to praktyczne odzwierciedlenie Singerowskiej teorii $\dot{z} y w y c h$ przekaźników. Dokonująca się poprzez retrospekcje transmisja treści usankcjonowanych 
kulturowo stanowi współcześnie również wzbogacanie owej przekazywanej tradycji. Otwiera nowy rozdział w myśleniu o stroju ludowym.

\section{Bibliografia}

Bazielich B. 1976. Moda w strojach regionalnych. Katowice: Biuro Wystaw Artystycznych.

Bazielich B. 1977. Ślaskie stroje ludowe. Katowice: Śląsk.

Bazielich B. 2002. Strój Rozbarski. Atlas Polskich Strojów Ludowych.Wrocław: Polskie Towarzystwo Ludoznawcze.

Bazielich B. 2017. Z bliska i z oddali. Stroje ludowe na Ślasku. Katowice: Muzeum Śląskie.

Białkowski A.2008. Standardy edukacji kulturalnej. Warszawa: Fundacja Polskiej Rady Muzycznej. Brzezińska A.W. 2013. Strój ludowy - od biografii przedmiotu do tożsamości podmiotu. [W:] A.W. Brzezińska, Tymochowicz M. (red.). Stroje ludowe jako fenomen kultury. Atlas Polskich strojów Ludowych. Wrocław: Polskie Towarzystwo Ludoznawcze, 15-22.

Biernacka M. (red.), 1976. Etnologia Polska. Przemiany kultury ludowej. Kraków: Instytut Historii Kultury Materialnej Polska Akademia Nauk.

Bittner-Szewczykowa H. 1976. Odzież chtopska jako dobro majątkowe (Tezauryzacja ubiorów chtopskich). Konteksty. Polska Sztuka Ludowa 30/1, 5-18.

Clarke A. E. 1991. Situational Analyses: Grounded Theory Mapping After the Postmodern Turn. Symbolic Interaction 26(4), 553-576.

Dudzik W. (red.) 2009. Rytuat dramat święto spektakl. Wstęp do teorii widowiska kulturowego. Warszawa: Uniwersytet im. Adana Mickiewicza.

Godlewski G. 2002. Animacja i antropologia. [W:] G. Godlewski, I. Kurz, A. Mencwel, M. Wójtowskiego (red.), Animacja kultury. Doświadczenie i przysztość. Warszawa: Instytut Kultury Polskiej Uniwersytet Warszawski, 56-70.

Goffman E. 2002. Cztowiek w teatrze życia codziennego. Warszawa: Aletheia.

Jaros J., Minkus J. 1969. Miasta, osiedla i gromady. [W:] H. Rechowicz (red.) Tarnowskie Góry. Zarys rozwoju powiatu., Katowice: Śląsk.

Jedlewska B. 2003. Animatorzy kultury wobec wyzwań edukacyjnych. Lublin: Uniwersytet im. Marii Skłodowskiej-Curie.

Kolankiewicz L. (red) 2010. Antropologia widowisk. Warszawa: Uniwersytet Warszawski, 10-32. Kuczob H. 2001. Dąbrórwka Wielka - dawniej i dzis. Chorzów: Centrum Usług Drukarskich.

Kuzio-Podrucki A. 2003. Henckel von Donnersmarckowie. Kariera i fortuna rodu. Bytom: Wydawnictwo Rococo.

Lysko A., Garstka R. (red.) 2018. Czas Niezwykty. Obrzędowoś́ doroczna na Górnym Ślasku. Katowice: Regionalny Instytut Kultury.

Dziadowiec J. 2011. Tradycyjne show, czyli sceniczny przekaz tradycji na przyktadzie regionalnych oper ludowych. [W:] P. Pilcht (red.), Przesztośc we wspótczesnej narracji kulturowej. Szkice kulturoznawcze. Kraków: Uniwersytet Jagielloński, 61-82.

Malewska-Szałygin A. 2008. Wyobrażenia o państwie i wtadzy we wsiach nowotarskich 1999-2005 Warszawa: Wydawnictwo DiG. 
McKenzie J. 2011. Performuj albo... Od dyscypliny do performensu. Kraków: Universitas. Mencwel A. 2006. Wyobraźnia antropologiczna. Warszawa: Uniwersytet Warszawski.

Pilińska W., Rakowski T. 2009. Badanie - Rozumienie - Dziatanie spoteczne. Projekt etnografi animacyjnej i etnograficznie zorientowanej animacji kultury. [W:] T. Rakowski (red.) Etnografialanimacja/sztuka. Nierozpoznane wymiary rozwoju kulturalnego. Warszawa: Narodowe Centrum Kultury, 32-50.

Piskorz-Branekova E. 2008. Polskie stroje ludowe I, Warszawa: Wydawnictwo MUZA.

Skórzyńska A. 2008. Gry i zabawy w perspektywie performatyki. O potrzebie badań interdyscyplinarnych w ludologii. Homo Communicativus. Filozofia - komunikacja-jezyk - kultura. 2(4), $31-45$.

Strauss A. 1978. A Social World Perspective. [W:] N. Denzin (ed.) Studies in Symbolic Interaction. Greenwitch: JAI Press, 119-128.

Strauss A. 1993. Continual Permutation of Action. New York: Aldine de Gruyter.

Schechner R. 2006. Performatyka. Wrocław: Ośrodek Badań Twórczości Jerzego Grotowskiego i Poszukiwań Teatralno-Kulturowych.

Toboła-Feliks M. 2020, Między tradycja a nowoczesnościq - twórcze i odtwórcze (re)konstrukcje stroju rozbarskiego. [W:] A.W. Brzezińska, M. Tymochowicz, A. Paprot-Wielopolska (red.) (Re)konstruowane stroje ludowe jako znak manifestowania tożsamości lokalnej. Atlas Polskich Strojów Ludowych 49. Wrocław: Polskie Towarzystwo Ludoznawcze.

Willis P. 2005. Wyobraźnia etnograficzna. Kraków: Uniwersytet Jagielloński.

\section{Archiwalia:}

Długosz J., Liber Beneficorum, III, 1470. IAiE PAN, sygn. III 158/9.

\section{Źródła internetowe:}

http://www.dwonline.pl/bozecialo2016.html, 11.12.2020 (link zarchiwizowany)

https://dabrowkawielka.pl/Zdjecia, 13.12.2020

https://slaskie.naszemiasto.pl/noc-muzeow-2014-w-katowicach-bezplatny-bus-i-zwiedzanie/ ar/c13-2719828, 7.01.2021

https://www.dabrowkaparafia.wiara.org.pl, 10.01.2020

Autorka:

Mgr Magdalena Toboła-Feliks

Muzeum Historii Katowic, Dział Etnologii Miasta

ul. Rymarska 4, 40-425 Katowice

e-mail: m.tobola-feliks@mhk.katowice.pl 
